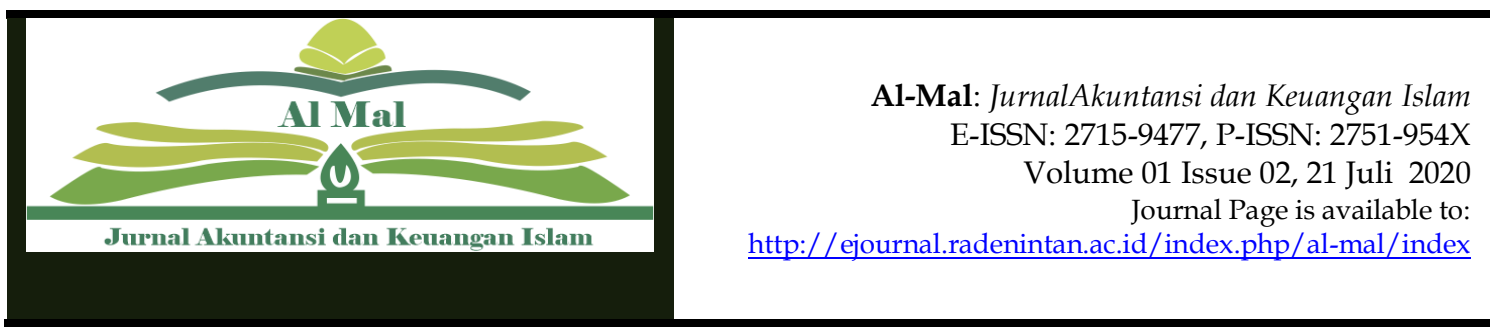

\title{
Analisis Penerapan Standar Akuntansi Pemerintahan Berbasis Akrual Pada Pemerintah Kota Kupang
}

Irene Thersya Henukh ${ }^{1 *}$, Mohammad Fathan Saleh², Rinaningsih ${ }^{3}$, Yang Elvi

Adelina 4

$\mathbf{1}^{*}, \mathbf{2 , 3 , 4}$ Departement of Economics, Faculty Accounting, Universitas Prasetya Mulya, Indonesia

\begin{tabular}{l}
\hline \multicolumn{1}{c}{ ARTICLE INFO } \\
\hline Article history: \\
Received 11-06-2020 \\
Revised 07-07-2020 \\
Accepted 09-07-2020 \\
Available 21-07-2020 \\
Revised (1) 18-07-2022 \\
Accepted 18-07-2022 \\
Revised Available 19-07-2022 \\
\hline Kata Kunci: \\
Akuntansi Berbasis Akrual, Standar \\
Akuntansi Pemerintahan, Teori \\
Implementasi, Teori Self-Efficacy \\
\hline Paper type: Research paper \\
\hline
\end{tabular}

Please cite this article: Henukh, I. T., Saleh, M. F., Rinaningsih, R., \& Adelina, Y. E. “Analisis Penerapan Standar Akuntansi Pemerintahan Berbasis Akrual Pada Pemerintah Kota Kupang" Al-Mal: Jurnal Akuntansi dan Keuangan Islam [ONLINE], Volume 01 Number 02 (Juli 21, 2020)

Cite this document: Al-Mal 2th edition

\section{${ }^{*}$ Corresponding author} e-mail:

Irene.henukh@student.pmsbe.ac.id

Page: 161-184

\begin{tabular}{l}
\hline \multicolumn{4}{c}{ ABSTRAK } \\
\hline Tujuan Penelitian ini untuk menganalisis \\
Penerapan Standar Akuntansi Pemerintahan \\
Berbasis Akrual Pada Penerintah Kota Kupang. \\
Metode pendekatan pada penelitian ini yaitu \\
metode studi kasus dengan pendekatan kualitatif, \\
sumber data yang digunakan yaitu data yang \\
diperoleh dari wawancara dan penyebaran \\
kuesioner sebagai data pendukung. Hasil dari \\
penelitian ini menunjukan bahwa pemerintah kota \\
Kupang telah menerapkan SAP berbasis akrual. \\
Hal tersebut dilihat dari jumlah pegawai, sarana \\
dan prasarana serta Teknologi Informasi (TI) \\
berupa Sistem Informasi Pengelolaan Keuangan \\
Daerah (SIPKD) yang memadai namun belum \\
optimal. Komunikasi berjalan secara langsung antar \\
pimpinan dengan pegawai namun juga belum \\
optimal, sedangkan komitmen dalam menjalankan \\
setiap kebijakan yang dibuat dan SOP yang \\
digunakan juga telah sesuai dengan panduan yang \\
diberikan oleh Pemerintah Pusat. Keterbatasan \\
pada penelitian ini terletak pada objek pengamatan \\
sehingga memberikan peluang untuk peneliti- \\
peneliti selanjutnya untuk melakukan penelitian \\
yang sama dengan menambahkan objek \\
pengamatan yang lebih luas. Implikasi pada \\
penelitian ini yaitu Analisis didasarkan pada \\
Peraturan Menteri Dalam Negeri Republik \\
Indonesia nomor 64 tahun 2013 perihal penerapan \\
Standar Akuntansi Pemerintahan berbasis akrual \\
pada pemerintah daerah. Pendekatan dalam \\
menganalisis faktor-faktor dan kendala yang \\
dihadapi oleh pemerintah kota Kupang dalam \\
penerapan SAP. \\
\hline Al-Mal with CC BY license. Copyright $\odot 2020$, the author(s) \\
\hline
\end{tabular}


ABSTRACT: The purpose of this study was to analyze the application of accrual-based government accounting standards in the Kupang city government. The approach method in this research is a case study method with a qualitative approach, the data sources used are data obtained from interviews and questionnaires as supporting data. The results of this study indicate that the Kupang city government has implemented accrual-based SAP. This can be seen from the number of employees, facilities and infrastructure as well as Information Technology (IT) in the form of the Regional Financial Management Information System (SIPKD) which is adequate but not yet optimal. Communication runs directly between leaders and employees but is also not optimal, while the commitment to implementing every policy made and the SOPs used are also in accordance with the guidelines provided by the Central Government. The limitation of this study lies in the object of observation so that it provides an opportunity for further researchers to conduct the same research by adding a wider object of observation. The implication of this research is that the analysis is based on the Regulation of the Minister of Home Affairs of the Republic of Indonesia number 64 of 2013 regarding the application of accrual-based Government Accounting Standards to local governments. Approach in analyzing the factors and constraints faced by the Kupang city government in the application of SAP..

Keyword: Accrual-Based Accounting, Government Accounting Standards, Implementation Theory, Self-Efficacy Theory

\section{PENDAHULUAN}

Peraturan Menteri Dalam Negeri Republik Indonesia (Permendagri) nomor 64 tahun 2013 perihal "Penerapan Standar Akuntansi Pemerintahan Berbasis Akrual pada Pemerintah Daerah" mulai diterapkan di berbagai Pemerintah Daerah di seluruh Indonesia sejak tahun 2015. Terdapat faktorfaktor yang memengaruhi penerapan SAP berbasis akrual pada Pemerintah Daerah. Hladika, Vasicek dan Dragija (2013) menyatakan bahwa penerapan sistem akuntansi berbasis akrual masih dalam tingkat ketidaksesuaian yang tinggi. Dalam era keterbukaan ini, masyarakat semakin menyadari hak dan kewajibannya sebagai warga negara dan lebih dapat menyampaikan aspirasi yang berkembang yang salah satunya perbaikan terhadap sistem pengelolaan keuangan pada badan-badan pemerintah (Sony Lamonisi, 2016). Beberapa kendala yang dihadapi sektor publik dalam penerapan akuntansi berbasis akrual mencakup Sumber Daya Manusia (SDM), sumber daya keuangan, 
kapasitas TI, serta durasi maupun kompleksitas proses pelaksanaan. Penelitian lain mendapat hasil yang tidak jauh berbeda mengenai kendala yang dihadapi dalam penerapan SAP berbasis akrual. Azmi dan Mohamed (2014) menyatakan akuntan pemerintah daerah telah siap untuk mengubah pola pikir dan percaya atas pengimplementasian akuntansi berbasis akrual. Dalam reformasi di bidang keuangan negara, perubahan yang signifikan adalah perubahan di bidang akuntansi pemerintahan yang transparan dan akuntabel menjadi isu yang sangat penting di pemerintahan Indonesia (Ni Made Ari Widyastuti dkk, 2015). Salah satu bagian dari reformasi keuangan negara adalah reformasi di bidang akuntansi pe-merintahan yaitu perubahan dari basis akuntansi kas menjadi basis akuntansi akrual. Dengan perubahan ini, diharapkan akan dapat meningkat-kan transparansi dan akuntabilitas pengelolaan keuangan negara serta mengikuti international best practices yang disesuaikan dengan kondisi di Indonesia (M. Dimas Satrio dkk, 2016).

Peraturan Menteri Keuangan (PMK) nomor 09 tahun 2015 perihal Standar Reviu Laporan Keuangan Pemerintah Pusat menyatakan bahwa Laporan Keuangan Pemerintah Pusat (LKPP) merupakan laporan pertanggungjawaban yang dilakukan untuk memenuhi pelaporan Anggaran Pendapatan dan Belanja Negara (APBN). Laporan keuangan tersebut disusun oleh Direktorat Akuntansi dan Pelaporan Keuangan yang penerbitannya dilakukan secara annually atau tahunan. LKPP berdasarkan fisiknya merupakan suatu pelaporan konsolidasi keuangan Kementerian Negara atau Kelembagaan yang disusun berdasarkan praktik standar Internasional Republik Indonesia dalam pengelolaannya pada keuangan negara. Sedangkan, Laporan Keuangan Pemerintah Daerah (LKPD) merupakan laporan pertanggungjawaban yang dilakukan untuk memenuhi pelaporan Anggaran Pendapatan dan Belanja Daerah (APBD). Akuntansi keuangan daerah terdiri atas akuntansi keuangan Pemerintahan Provinsi dan Pemerintahan Daerah. Laporan Keuangan disusun dengan metode penyusunan yang terdiri dari tujuh pelaporan dasar, yaitu Laporan Realisasi APBN, Laporan Perubahan Saldo Anggaran Lebih (SAL), 
Neraca, Laporan Operasional, Laporan Arus Kas, Laporan Perubahan Ekuitas, dan Catatan atas Laporan Keuangan.

SAP berbasis akrual mulai diterapkan pada tahun 2015 oleh Pemerintah Daerah diseluruh Indonesia. Hal ini memberi kemajuan bagi laporan keuangan pemerintah yang lebih efektif dan transparan. Namun, dalam menerapkan suatu sistem atau kebijakan baru tidak terlepas dari berbagai faktor serta kendala yang dihadapi. Hal tersebut menjadi pembahasan dalam penelitian dengan tujuan menganalisis faktor-faktor serta kendala yang memengaruhi keberhasilan atas penerapan SAP berbasis akrual di Badan Keuangan Daerah (BKD) Kota Kupang, Nusa Tenggara Timur. Akuntansi dengan basis akrual ini dianggap lebih baik daripada basis kas, karena akuntansi berbasis akrual diyakini dapat menghasilkan laporan keuangan yang lebih dapat dipercaya, lebih akurat, komprehensif, dan relevan untuk pengambilan keputusan ekonomi, sosial dan politik (Tengu Azman, 2015).

Mulyana (2009) menyatakan bahwa New Zealand merupakan negara pertama yang mengimplementasikan basis akrual sebagai bagian dari reformasi sektor pemerintah pada akhir tahun 1990. Selanjutnya penerapan basis akrual diikuti oleh Swedia yang menerapkan basis akrual dalam tingkat kementerian dan pada tingkat konsolidasian dengan penerapan basis akrual penuh (full accrual) pada laporan keuangannya dengan pengecualian terhadap perlakuan aset bersejarah dan pajaknya (Sari dan Putra, 2012). Australia dan New Zealand merupakan negara-negara pertama yang mengimplementasikan akuntansi berbasi akrual secara popular (Yuliati, Yuliansyah \& Adelina, 2019). Di Australia, seluruh departemen telah mempersiapkan laporan keuangan berbasis akrual di tahun 1994 melalui reformasi anggaran, dimana Komisi Nasional Audit merekomendasikan anggaran basis akrual sebagai pengganti dari anggaran berbasis kas (Sari dan Putra, 2012).

Selain penelitian dari berbagai negara di atas, penelitian lain mengenai akuntansi pemerintahan berbasis akrual juga dilakukan beberapa pemerintah daerah di Indonesia. Widyastuti, Sujana, dan Adiputra (2015), menganalisis 
kesiapan Pemerintah Daerah dalam menerapkan SAP berbasis akrual di Kabupaten Gianyar, mendapatkan hasil bahwa SAP berbasis akrual masih dalam tahapan persiapan seperti kesiapan dalam hal kualitas SDM yang belum sepenuhnya menguasai basis akrual dikarenakan keterbatasan dalam menggunakan Sistem Informasi Manajemen Daerah (SIMDA). Hal ini perlu dilengkapi dengan pelatihan-pelatihan khusus bagi para pegawai serta pihakpihak terkait, terutama dalam hal kesiapan software dan hardware dari segi TI untuk mendukung sistem tersebut. Selain SDM dan TI, yang perlu diperhatikan adalah komitmen dari organisasi atau pemerintah dalam mendukung peraturan pemerintah yang sudah ada dan dalam penerapannya. Pada penelitian di Palembang, Maimunah (2016) menyatakan pengimplementasian penerapan SAP berbasis akrual masih belum diterapkan secara keseluruhan atau $100 \%$, hal ini juga dikarenakan faktor SDM yaitu, kurangnya sosialisasi dan juga pengetahuan para pegawai pemerintah daerah di Kota Palembang dalam penerapannya akuntansi secara akrual.

Dalam penelitian Putra dan Ariyanto (2015), terdapat beberapa faktor yang memengaruhi penerapan SAP berbasis akrual di Pemerintah Daerah. Hal yang menjadi faktor utama adalah SDM. Dalam penelitian Pratama (2012), terlihat beberapa faktor bahwa kompetensi SDM, praktik keuangan publik dan regulasi merupakan faktor yang membuat permasalahan dalam aplikasi akuntansi akrual di Indonesia. Penerapan SAP berbasis akrual dinilai dapat memberikan dan mewujudkan akuntabilitas dan transparansi dalam pelaporan keuangan pemerintahan terutama dalam hal pelaporan nilai aset pemerintah (Tarigan dan Nurtanzila, 2013).

Penelitian ini memberikan manfaat dalam memberikan pengetahuan yang lebih mendalam akan implementasi SAP berbasis akrual terhadap pemerintah kota Kupang hingga Pemda lain yang masuk dalam lingkup Provinsi Nusa Tenggara Timur. Kedua, penelitian memberikan gambaran lebih kepada Kementrian Keuangan sebagai pihak yang membuat kebijakan dalam pelaporan keuangan dari Pemerintah Daerah, meminimalisirkan kendala yang 
masih terjadi dengan pembuatan kebijakan-kebijakan yang baru. Ketiga, memberikan manfaat kepada akademisi dengan melihat hasil berupa faktorfaktor yang memengaruhi penerapan Standar Akuntansi berbasis akrual pada Pemerintah Kota Kupang berupa sumber daya, komunikasi, disposisi atau sikap, dan struktur birokrasi, serta self-efficacy yang merupakan keyakinan dari setiap pihak dapat memberikan pengetahuan tambahan kepada setiap akademisi di bidang ekonomi dan akuntansi. Selain itu, kendala yang terjadi dalam proses implementasi dapat memberi gambaran dalam mengembangkan ilmu Akuntansi Sektor Publik sehingga dapat dipergunakan dengan sebaikbaiknya serta berguna bagi generasi masa depan.

Penetapan pemerintah kota Kupang sebagai objek penelitian didasari pada tiga hal. Pertama, kota Kupang merupakan ibukota Provinsi Nusa Tenggara Timur serta menjadi cerminan dan contoh bagi pemerintah daerah di Kabupaten lain yang ada di Nusa Tenggara Timur. Kedua, letaknya yang jauh dari pusat pemerintahan sehingga pelaksanaan SAP berbasis akrual perlu diteliti dan dievaluasi lebih lanjut. Ketiga, hal yang paling penting yaitu kota Kupang masih memiliki opini WDP (Wajar Dengan Penegecualian) yang diberikan oleh Badan Pemeriksa Keuangan (BPK) Provinsi Nusa Tenggara Timur terhadap Laporan Keuangan Pemerintah Daerah tahun anggaran 2017.

Selanjutnya penjelasan penelitian ini terdiri atas telaah literatur yang menjelaskan mengenai landasan teori yang memperkuat analisis penelitian. Kemudian metode penelitian mengenai perolehan data serta proses pengolahan data untuk menemukan hasil analisis. Terakhir adalah hasil dan diskusi yang memuat pembahasan atas analisis penelitian serta adanya kesimpulan, implikasi dan keterbatasan yang mendukung.

\section{METODOLOGI PENELITIAN}

Penelitian studi kasus mengenai SAP berbasis akrual tahun 2013 pada Pemerintah Kota Kupang dilaksanakan dalam periode waktu bulan September tahun 2017 sampai dengan bulan September tahun 2018, dengan meneliti 
mengenai faktor-faktor serta kendala yang memengaruhi penerapan SAP berbasis akrual. Pemerintah kota Kupang menjadi objek penelitian dengan berfokus pada BKD Kota Kupang.

Miles dan Huberman (1984) mengemukakan bahwa terdapat tiga aktivitas analisis data yaitu reduksi data (data reduction), penyajian data (data display), dan konklusi (verification). Reduksi data mencakup merangkum, memilih data-data yang menjadi pokok pembahasan dan analisis, mendata halhal penting dan menghapus data yang tidak diperlukan. Setelah melakukan reduksi data, langkah selanjutnya yaitu melakukan penyajian atas data yang telah dibuat. Penyajian data dapat dibuat dalam bentuk uraian, bagan, hubungan antar kategori, tabel, grafik, dan lain sebagainya. Proses analisis data terakhir adalah membuat kesimpulan dan saran atas hasil yang diperoleh dari proses reduksi data dan penyajian data. Dengan hasil analisis dan pembahasan yang dibuat maka diperlukan kesimpulan serta saran yang membangun untuk penelitian.

Skala rating merupakan salah satu dari berbagai skala pengukuran yang dapat digunakan sebagai acuan dasar dalam mengukur sikap dan persepsi responden terhadap suatu fenomena, seperti skala yang dapat mengukur pengetahuan, kemampuan, keahlian dan lain-lain. Sugiyono (2009:97) menyatakan bahwa rating scale adalah data mentah yang diperoleh berupa angka kemudian ditafsirkan dalam pengertian kualitatif. Sedangkan, Arikunto (2006:158) menyatakan rating scale merupakan sebuah pernyataan yang diikuti oleh jawaban-jawaban yang menunjukkan tingkatan-tingkatan. Dengan kata lain, skala ini memberikan alternatif jawaban yang berbeda dengan skor nilai yang beragam. Atas dasar pengertian tersebut, maka skala yang digunakan pada kuesioner adalah skala rating dengan memberikan skor nilai pada jawaban, dengan pengadaptasian kuesioner menggunakan teori implementasi Edward (1980) dan Bandura (1986). Skala penilaian menggunakan skor dengan tingkatan nilai 0 (nol) sampai dengan 100 (seratus). Nilai nol merupakan hasil terendah dan nilai seratus merupakan hasil tertinggi dalam kuesioner. Dari 
kelima nilai yang telah disediakan di dalam kuesioner, responden lalu harus memilih memberikan skoring pada kolom jawaban yang telah disediakan dan didampingi instrumen dalam bentuk pernyataan ataupun pertanyaan.

\section{HASIL DAN PEMBAHASAN}

A. Analisis Faktor-faktor yang Memengaruhi Keberhasilan Penerapan SAP

Berbasis Akrual di Pemerintah Kota Kupang Analisis Aspek Sumber Daya

Pada aspek sumber daya, pertanyaan dan pernyataan yang diberikan kepada narasumber serta responden terkait dengan jumlah pegawai, kualitas dan latar belakang pendidikan pegawai, sarana prasarana yang tersedia, pengiriman laporan keuangan kepada BPK, sistem aplikasi yang digunakan, insentif bagi pegawai, pelatihan, dan mutasi pegawai.

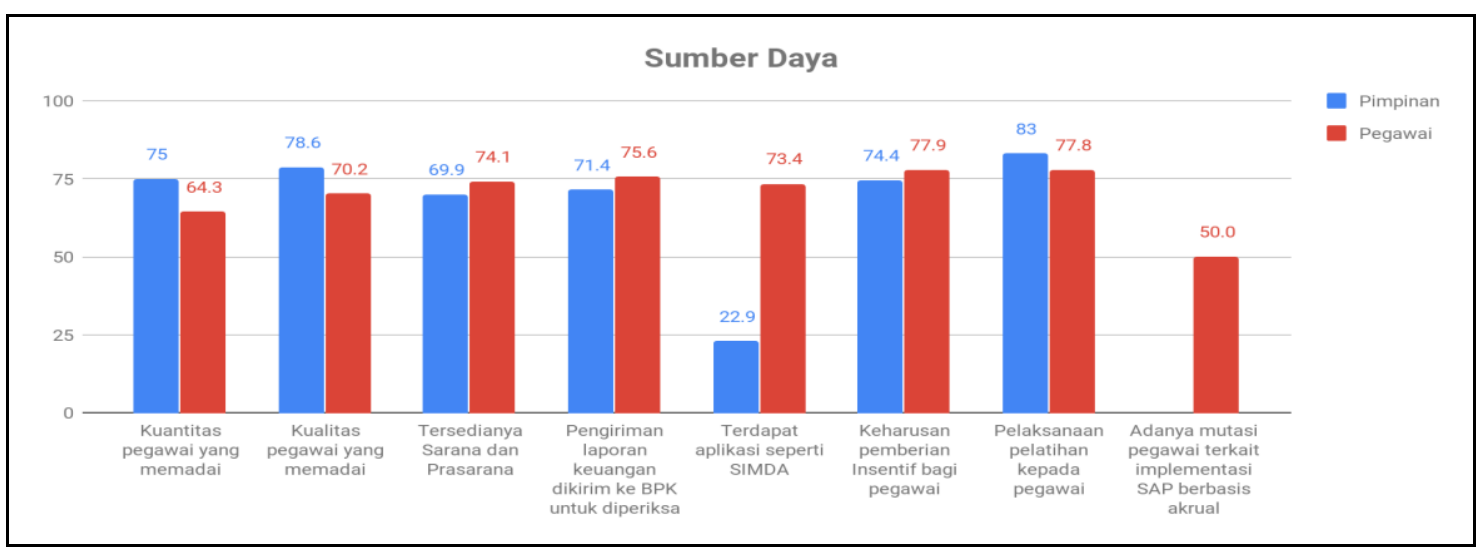

Gambar 1 Grafik Hasil Kuesioner Sumber Daya

Sumber: Data Diolah

Berdasarkan tabel 1 dan gambar 1 data hasil kuesioner Kepala Badan/Bidang/Sekretaris dan Pegawai di BKD Kota Kupang, nilai yang diperoleh masuk dalam kategori setuju dengan nilai rata-rata yaitu 67,9 untuk Kepala Badan/Bidang/Sekretaris dan 71,3 untuk pegawai. Sedangkan pada grafik menunjukan rata-rata nilai dari pimpinan dan pegawai yang mencakup pernyataan dan pertanyaan kuesioner yang berkaitan dengan sumber daya yang mempengaruhi implementasi SAP berbasis akrual. 


\section{a. Jumlah Pegawai Badan Keuangan Daerah Kota Kupang}

Pada pernyataan kuesioner pertama mengenai jumlah pegawai, pimpinan atau pejabat memiliki nilai rata-rata sebesar 75 yang berarti sangat setuju dan pegawai dengan rata-rata 64,3 yang artinya setuju. Angka tersebut menunjukan bahwa pimpinan maupun pegawai memiliki pendapat yang sama, yakni jumlah pegawai yang bekerja di BKD Kota Kupang sudah memadai. Selain data kuesioner, hasil dari wawancara bersama Kepala Badan dan beberapa pimpinan lain, diketahui bahwa jumlah pegawai yang bekerja di BKD sudah cukup dengan total sebanyak 232 pegawai yang terbagi menjadi beberapa divisi. Namun, salah satu narasumber yaitu Ibu Evelyn selaku Kepala Bidang Aset dan Akuntansi di BKD Kota Kupang, menyatakan bahwa jumlah pegawai yang bekerja pada bidang aset dan akuntansi masih terbilang kurang. Jumlah pegawai yang aktif bekerja hanya 7 orang dan 4 orang lain yang membantu untuk pekerjaan kecil lainnya seperti melakukan penggandaan dokumen (fotocopy). Diperlukan adanya penambahan pegawai khususnya dengan latar belakang akuntansi untuk dapat membantu pekerjaan yang ada sehingga lebih efektif.

b. Kualitas dan Latar Belakang Pendidikan

Pernyataan kedua pada aspek sumber daya mengenai kualitas dan latar belakang pendidikan dari setiap pegawai di BKD Kota Kupang. Cahyadi (2009) dalam Pristiani dan Mahmud (2016) menyatakan bahwa tingkat pendidikan berpengaruh terhadap pemahaman dalam pembuatan laporan keuangan pemerintahan berbasis akrual. Bapak Jefri Pelt selaku Kepala Badan memberikan pernyataan bahwa kualitas dari setiap pegawai sudah sangat baik dalam mengerjakan setiap pekerjaan terkait dengan SAP berbasis akrual. Kualitas yang baik diperoleh dari kebiasaan dan pekerjaan yang dilakukan secara rutin dan berkala. Setiap pegawai juga ditempatkan pada divisi sesuai dengan kemampuan masing-masing. Namun, jika melihat dari latar belakang pendidikan pegawai, jumlah pegawai yang 
berlatar belakang pendidikan akuntansi masih sangat sedikit. Pernyataan ini diperoleh dari bapak Jefry Pelt bahwa hampir semua PNS (Pegawai Negeri Sipil) yang bekerja memiliki latar belakang pendidikan yang berbeda-beda. Pernyataan ini juga didukung dengan pernyataan dari Bapak Johanis bahwa perlu adanya pengembangan lebih lanjut terkait dengan pendidikan akuntansi di Nusa Tenggara Timur. Hal ini perlu menjadi perhatian pemerintah dalam membangun dan mengembangkan tingkat pendidikan akuntansi di Nusa Tenggara Timur melalui kebijakankebijakan yang dibuat. Misalnya memberikan jalur beasiswa kepada pelajar untuk melanjutkan pendidikan jurusan akuntansi, sehingga dapat membantu mengembangkan potensi-potensi yang ada.

c. Sarana dan Prasarana

Sarana prasarana yang tersedia dalam mendukung seluruh pekerjaan di BKD Kota Kupang sudah cukup memadai. Menurut Bapak Jefri Pelt, peralatan kantor seperti komputer, lemari, dan pendukung lainnya sudah lengkap. Setiap petugas lapangan yang bertugas di luar kantor juga difasilitasi dengan laptop sehingga mendukung dalam pengerjaan di lapangan. Laporan keuangan yang telah dibuat diperiksa oleh BPK Provinsi di Kota Kupang.

d. Aplikasi Teknologi Informasi Berbasis Akrual

Hasil yang diperoleh dari kuesioner Kepala Badan/Bidang/Sekretaris yaitu dengan nilai rata-rata sebesar 22,9. Terdapat empat orang pimpinan yang menjawab dengan memberi nilai nol, artinya responden sangat tidak setuju bahwa aplikasi TI yang digunakan untuk mendukung pengerjaan laporan keuangan berbasis keuangan adalah SIMDA. Sedangkan pada hasil kuesioner pegawai memberikan hasil yang berbeda dengan nilai rata-rata sebesar 73,4. Setelah melakukan kompilasi dengan hasil wawancara, diketahui bahwa terdapat perubahan pada penggunaan aplikasi pendukung dalam pengerjaan pelaporan keuangan Pemerintah Daerah Kota Kupang. Sejak tahun 2015, pemerintah daerah menggunakan aplikasi 
SIMDA dalam pengerjaan laporan keuangan, namun terhitung sejak tahun 2018 aplikasi tersebut sudah tidak lagi digunakan. Ibu Evelyn Venita selaku Kepala Bidang Akuntansi dan Aset BKD kota Kupang memberikan pernyataan bahwa terjadi pergantian aplikasi dari SIMDA ke SIPKD pada tahun 2018, yang secara resmi dikeluarkan oleh Direktorat Jenderal Keuangan Daerah sebagai sarana aplikasi yang dapat membantu meningkatkan efektivitas implementasi laporan keuangan daerah berbasis akrual. Dari hasil tersebut, dapat dianalisis bahwa perbedaan ini terjadi karena kurangnya sosialisasi kepada seluruh pimpinan maupun pegawai akan perubahan sistem aplikasi TI yang digunakan oleh BKD dalam mendukung pengerjaan laporan keuangan sesuai dengan SAP berbasis akrual. Perlu adanya sosialisasi secara menyeluruh dari pemerintah sehingga SIPKD dapat dipahami dan diaplikasikan dalam pengerjaan laporan keuangan. Selain itu, masih terdapat ketergantungan akan pembuatan laporan keuangan secara manual dengan menggunakan microsoft excel. Hal ini mengakibatkan aplikasi SIPKD belum sepenuhnya dipahami dan dipergunakan sebagaimana mestinya. Penelitian terdahulu yang dilakukan oleh Widyastuti, Surjana, dan Adiputra (2015) mendapat hasil yang sama mengenai aplikasi TI. Hasil yang diperoleh dari penelitian tersebut berupa kualitas SDM yang belum sepenuhnya menguasai akuntansi berbasis akrual serta keterbatasan dalam menggunakan aplikasi SIMDA. Permasalahan tersebut perlu diatasi dengan pengadaan pelatihan kepada pegawai serta pihak-pihak terkait. Dengan demikian, BKD Kota Kupang perlu melakukan evaluasi serta berkomitmen untuk menerapkan dan meningkatkan kualitas SDM dalam penggunaan aplikasi SIPKD.

e. Pelatihan

Salah satu faktor penting dalam mendukung kualitas kerja dan kemampuan dari setiap pihak untuk dapat memberikan hasil kinerja yang baik yaitu pelatihan. Kepala Badan/Bidang atau Sekretaris pegawai menunjukan nilai rata-rata diatas 70 . Hasil tersebut menyatakan bahwa 
semua responden setuju dengan adanya pelatihan yang diberikan. Jenis pelatihan yang diberikan berupa bimbingan teknis mengenai implementasi SAP berbasis akrual untuk keuangan daerah dan implementasi paket regulasi pengelolaan keuangan daerah. Pelatihan tersebut dilaksanakan pada bulan April dan Desember dalam satu tahun, dengan menggunakan fasilitator dari Badan Pengawasan Keuangan dan Pembangunan (BPKP) Provinsi Nusa Tenggara Timur serta kementerian terkait. Informasi yang diperoleh dari wawancara memberikan hasil yang sama dengan kuesioner. Bapak Jefri Pelt menyatakan bahwa setiap pimpinan dan pegawai wajib mengikuti kegiatan pelatihan atau Bimtek (Bimbingan Teknis) yang diadakan oleh Pemerintah. Terdapat dua kegiatan pelatihan yang dilaksanakan yaitu oleh Pemerintah Pusat dan Pemerintah Provinsi. Pemerintah Pusat mengadakan kegiatan pelatihan yang berpusat di Jakarta dengan mengundang setiap Kepala Daerah serta beberapa pegawai yang menjadi perwakilan untuk dapat mempelajari setiap proses dan aspek dalam implementasi SAP berbasis akrual. Dengan hasil pelatihan yang diperoleh dari Pemerintah Pusat, setiap peserta pelatihan akan memberikan informasi tersebut kepada seluruh pegawai yang bekerja di BKD Kota Kupang. Selain itu, Pemerintah Provinsi juga mengadakan kegiatan pelatihan atau Bimtek di Kota Kupang dengan mengundang seluruh perwakilan dari tiap kabupaten yang ada di Provinsi Nusa Tenggara Timur. Pelatihan ini menggunakan jasa dari BPK Provinsi yang diadakan sebanyak dua kali dalam satu tahun sehingga memberikan pemahaman yang lebih baik kepada seluruh pegawai.

f. Sistem Mutasi Pegawai

Pernyataan terakhir pada aspek sumber daya mengenai mutasi pegawai terkait dengan penerapan SAP berbasis akrual. Dari data tersebut (table dan gambar 1) menunjukan adanya mutasi pegawai yang dilakukan pada divisi tertentu. Sejumlah pegawai menyatakan tidak setuju dengan adanya 
mutasi terhadap pegawai dengan rata-rata nilai yaitu 50. Namun, Kepala BKD Kota Kupang menyatakan bahwa proses mutasi pegawai merupakan hal yang wajar dan dapat terjadi di seluruh Pemerintah Daerah di Indonesia. Mutasi pada BKD Kota Kupang dilakukan melalui dua kebijakan dengan menggunakan sistem rolling atau pemindahan yang dilakukan secara langsung oleh pihak internal dan didasarkan pada tingkat pengetahuan bimtek yang telah diperoleh pegawai. Kebijakan mutasi dilakukan setelah pegawai sudah bekerja selama lebih dari dua sampai tiga tahun, yang menunjukan tingkat pemahaman dan kinerja cukup baik dalam bidangnya. Jika diperhatikan lebih jauh, seorang pegawai idealnya dapat memahami dan menguasai seluruh pekerjaan dan kebijakan yang ada kurang lebih satu sampai dengan dua tahun bekerja. Jika pada tahun kedua atau ketiga seorang pegawai dimutasi, kemudian terjadi pergantian dengan pegawai baru, hal ini menjadi permasalahan bagi internal BKD. Perlu adanya adaptasi bagi pegawai yang baru ditempatkan dalam divisi tertentu, dengan melihat pada beban pekerjaan yang diperoleh dan kemampuan pegawai pada divisi yang ditempatkan. Pegawai yang belum dapat menyelesaikan tugasnya dengan baik dan beradaptasi di lingkungan kerja barunya mengakibatkan penumpukan pada pekerjaan. Sedangkan permasalahan lainnya yaitu pegawai mengalami kesulitan dalam menyesuaikan keahlian yang dimiliki dengan pekerjaan. Kedua masalah ini menjadi hambatan pada Kantor BKD. Oleh karena itu, perlu adanya bantuan serta dukungan dari pegawai yang sudah berpengalaman dan memiliki pengetahuan lebih di bidangnya untuk membantu pegawai baru dalam menyesuaikan pekerjaan barunya. Proses mutasi terhadap pegawai ditangani langsung oleh Walikota yang didasari pada masukan dan pendapat dari Satuan Kerja Perangkat Daerah (SKPD). Bapak Jefry memberi saran agar setiap SKPD di Kota Kupang dapat mengambil sikap dan memberi masukan yang baik sehingga sistem mutasi terhadap pegawai 
diperbaiki. Hal ini berguna untuk menjalankan pekerjaan dalam penerapan akuntansi berbasis akrual.

B. Analisis Kendala Implementasi SAP berbasis Akrual di Pemerintah Kota Kupang

Penyesuaian terhadap suatu kebijakan baru tidak terlepas dari masalah. Baik dari Pemerintahan Pusat maupun Pemerintahan Daerah, beberapa permasalahan terkait dengan implementasi SAP berbasis akrual masih terjadi. Merujuk pada pembahasan mengenai faktor-faktor yang mempengaruhi implementasi SAP berbasis akrual, masih terdapat beberapa kendala yang dihadapi oleh BKD Kota Kupang. Berdasarkan informasi yang diperoleh dari narasumber, BPK Provinsi Nusa Tenggara Timur memberikan opini terhadap Laporan Keuangan Pemerintah Daerah tahun anggaran 2017 Pemerintah Kota Kupang pada bulan Mei 2018. Berikut ini merupakan analisis kendala yang dihadapi oleh pemerintah kota Kupang yang didasarkan pada faktor-faktor yang memengaruhi penerapan SAP berbasis akrual.

a. Kendala Sumber Daya

Dalam penelitian Widyastuti, Sujana, dan Adiputra (2015), kendala yang dihadapi oleh pemerintah yaitu faktor SDM, dilihat dari pemahaman pegawai yang berbeda dengan kualitas yang belum memadai. Pemerintah kota kupang mengalami kendala yang tidak jauh berbeda dengan peneltian terdahulu. Bapak Jefry Pelt selaku Kepala BKD Kota Kupang dan Ibu Evelyn Vennita selaku Kepala Bidang Aset dan Keuangan memberikan pernyataan bahwa jumlah pegawai yang bekerja di BKD Kota Kupang sudah cukup memadai, namun penguasaan akan kebijakan dan penyusunan laporan keuangan dari setiap pegawai masih sangat rendah. Kendala Kualitas dan Latar Belakang Pendidikan

Merujuk pada penjelasan sebelumnya, pengembangan terhadap kualitas dan latar belakang pendidikan pegawai di bidang akuntansi perlu ditingkatkan. Peningkatan kualitas pegawai didukung dengan tingkat pendidikan yang sesuai dengan bidangnya. Pemerintah Kota Kupang masih 
terkendala kurangnya SDM dengan latar belakang pendidikan akuntansi. Cahyadi (2009) dalam Pristiani dan Mahmud (2016) menyatakan bahwa tingkat pendidikan berpengaruh terhadap pemahaman laporan keuangan daerah. Tingkat pendidikan didukung dengan latar belakang pendidikan yang sesuai dengan bidang pekerjaan akuntansi. Oleh karena itu, pemerintah perlu melakukan kebijakan atas kendala tersebut dengan meningkatkan pendidikan dibidang akuntansi bagi SDM di Nusa Tenggara Timur. Salah satu cara dengan membuka jalur beasiswa untuk pendidikan akuntansi yang nantinya akan berguna bagi peningkatan sumber daya dan kualitas dalam akuntansi. Jika pemerintah tetap mempertahankan penerimaan PNS dengan latar belakang pendidikan yang berbeda dan tidak sesuai dengan bidangnya, permasalahan tidak akan terselesaikan dan terus terjadi serta ketidakefektifan dalam hasil kinerja khususnya pada penerapan SAP. Penerapan SAP Berbasis Akrual dapat dilaksanakan secara bertahap dari penerapan SAP Berbasis Kas Menuju Akrual menjadi penerapan SAP Berbasis Akrual. Ketentuan lebih lanjut mengenai penerapan SAP Berbasis Akrual secara bertahap pada pemerintah pusat diatur dengan Peraturan Menteri Keuangan, sedangkan untuk pada pemerintah daerah diatur dengan Peraturan Menteri Dalam Negeri (Ni Nengah Dwi Wiryaningsih dkk, 2017).

b. Kendala Penggunaan Aplikasi SIPKD

Sehubungan dengan aplikasi SIPKD yang digunakan oleh BKD kota Kupang, ditemukan kendala terhadap kurangnya pengetahuan pimpinan dan pegawai atas informasi aplikasi tersebut. Salah satu faktor yang memengaruhi yaitu belum adanya sosialisasi secara jelas kepada seluruh pegawai yang bekerja di BKD Kota Kupang. Akibatnya terjadi perbedaan perspektif dari pembuat laporan keuangan dengan sistem baru yang dikeluarkan. Seharusnya saat SIPKD dicanangkan untuk dimplementasikan, pimpinan mengambil kebijakan dengan mengadakan pelatihan kepada seluruh pegawai di BKD Kota Kupang, sehingga pegawai memiliki pengetahuan dan pemahaman yang baik akan proses dan pembuatan 
laporan. Hal tersebut dapat membantu pengerjaan laporan keuangan dengan tidak hanya mengandalkan satu orang. Internal control yang ada di BKD Kota Kupang terhadap laporan keuangan juga menjadi lebih baik.

c. Kendala Tingkat Keyakinan atas Pelatihan

Pelatihan mengenai SAP berbasis akrual dilaksanakan oleh Pemerintah Pusat dan Pemerintah Provinsi atau Daerah. Pelatihan tidak diikuti seluruh pegawai, namun diwakili oleh beberapa pegawai yang kemudian akan diinformasikan mengenai hasil pelatihan tersebut. Akibatnya, pencapaian hasil yang didapatkan masih kurang maksimal. Pemerintah Daerah harus lebih memperhatikan dampak yang terjadi atas penerapan pelatihan implementasi SAP berbasis akrual, apakah sudah cukup efektif bagi pengerjaan pelaporan keuangan bagi pemerintah kota Kupang atau justru membuat pegawai mengalami kesulitan. Kurangnya keyakinan diri dari setiap pegawai juga menjadi masalah di BKD Kota Kupang. Sebagian besar pegawai masih belum sepenuhnya memiliki keyakinan dalam menyusun laporan keuangan berbasis akrual yang diakibatkan dari kurangnya penguasaan akan kebijakan SAP dan masih mempercayakan pekerjaannya kepada satu orang saja yaitu Bapak johanis Padabain. Masalah keyakinan diri pada pegawai akan berdampak pada pencapaian penyusunan laporan keuangan yang tidak maksimal. Pada penjelasan sebelumnya mengenai self-efficacy theory, pemerintah kota Kupang dapat meminimalisir kendala tersebut dengan meminta dukungan lebih dari BPK dalam meningktakan pendidikan dan pengetahuan pegawai terhadap SAP berbasis akrual.

d. Kendala Mutasi Pegawai

Pada analisis faktor yang memengaruhi penerapan SAP berbasis akrual di BKD kota Kupang, terdapat permasalahan mutasi terhadap pegawai. Hal ini menjadi kendala dalam proses implementasi. Dalam pemerintahan kota, terdapat sistem kenaikan pangkat, sehingga jika salah satu pegawai diberi kenaikan pangkat, maka terjadi mutasi ke bidang lain. 
Permasalahannya adalah terjadi pergantian pegawai dari pegawai yang telah dimutasi ke pegawai baru. Pegawai baru harus bisa menyesuaikan diri dalam pemahaman akan pekerjaan.

e. Kendala Keterlambatan Pelaporan Keuangan oleh SKPD

Setiap SKPD diberikan tanggung jawab untuk memberikan laporan realisasi anggaran sesuai dengan jangka waktu yang ditetapkan. Namun, dalam pelaksanaannya masih terdapat keterlambatan pelaporan, yang berdampak pada pembuatan laporan keuangan di BKD Kota Kupang oleh Bapak Johanis Padabain. Pimpinan harus membuat kebijakan tegas terhadap setiap SKPD sehingga dapat memberikan laporan sesuai dengan waktu yang ditetapkan. Terkait dengan keterlambatan SKPD dalam memberikan Laporan Realilsasi Anggaran, belum ada sanksi tegas dari pemerintah untuk mengurangi hal tersebut. Bapak Jefry menjelaskan bahwa sanksi yang diberikan hanya berupa teguran secara lisan. Jika pemerintah ingin agar SKPD lebih disiplin dan taat pada aturan yang ada, perlu adanya pembuatan kebijakan mengenai sanksi.

f. Kendala Teknis Penyusutasn Aset Tetap

Menurut Bapak Johanis Padabain selaku Staf Tenaga Fungsional Akuntansi di BKD Kota Kupang, terdapat beberapa informasi terkait dengan kendala dan tantangan yang dihadapi oleh Pemerintah Daerah Kota Kupang dalam Implementasi SAP berbasis akrual secara teknis. Hal ini berhubungan dengan kebijakan yang dalam Lampiran SAP berbasis akrual. Pada lampiran I Permendagri 64 tahun 2013 halaman 15 tentang penyusutan aset tetap yang menyatakan Aset Tetap Lainnya berupa hewan, tanaman, dan buku perpustakaan tidak dilakukan penyusutan secara periodik, melainkan diterapkan penghapusan pada saat aset tetap Lainnya tersebut sudah tidak dapat digunakan atau mati. BKD masih mempertanyakan mengenai penentuan nilai dan pencatatan jurnal terhadap aset tetap tersebut. Selain itu, berkaitan dengan masa manfaat aset tetap, BKD Kota Kupang juga masih mempertanyakan mengenai penentuan dari masa manfaat aset tetap serta 
penjelasan lebih jelas mengenai syarat dan kriteria yang harus digunakan untuk menentukan umur ekonomis atau masa manfaat suatu aset tetap.

Penelitian Dollah, Saerang, dan Manossoh (2015) menemukan kendala yang berhubungan dengan aset tetap yaitu adanya aset tetap tanah dan kendaraan bermotor yang tidak memiliki dokumen kepemilikannya sehingga aset tetap tersebut tidak memiliki nilai. Permasalahan tentang penentuan aset tetap serta pencatatan jurnalnya merupakan hal teknis yang terjadi dalam menerapkan suatu kebijakan baru. BKD Kota Kupang perlu melakukan penyesuaian sesuai dengan peraturan kebijakan yang dikeluarkan oleh Kementerian. Bapak Johanis memberikan pernyataan bahwa pemerintah kota Kupang masih membuat laporan keuangan dengan cara manual menggunakan microsoft excel. Semua format dalam pembuatan laporan keuangan dibuat dan dikembangkan sendiri oleh Bapak Johanis. Selama implementasi SAP berbasis akrual diterapkan, pembuatan laporan tidak menjadi masalah karena mengikuti standar yang digunakan oleh BKD Kota Kupang. Hal tersebut juga didukung dengan pernyataan yang disampaikan oleh Bapak Jefry dan Ibu Evelyn. Pemerintah Provinsi juga menerima hasil laporan keuangan dengan sangat baik dan memberi kepercayaan sepenuhnya kepada BKD Kota Kupang.

Dengan dikeluarkannya aplikasi SIPKD dapat membantu mempermudah pemerintah dalam membuat laporan keuangan. Oleh karena itu, kebijakan untuk menggunakan SIPKD dalam pembuatan pelaporan keuangan.

Kendala dalam penerapan SAP berbasis akrual tidak hanya terjadi di pemerintah kota Kupang, tetapi sebagian besar pemerintah daerah di Indonesia menghadapi kendala yang tidak jauh berbeda. Dollah, Saerang, dan Manossoh (2015) melakukan penelitian tentang analisis implementasi SAP berbasis akrual pada pemerintah Kabupaten Bolaang Monggodow Utara. Hasil penelitian tersebut menyatakan beberapa kendala yang dihadapi oleh pemerintah daerah antara lain SDM yang belum cukup memadai dalam mengelola laporan keuangan, sering terjadi pergantian pegawai di bidang pengelolaan aset, serta 
aplikasi yang datanya belum terintegrasi satu dengan lainnya. Kendala lain yang dihadapi oleh pemerintah Kabupaten Bolang yaitu keterlambatan penyampaian data dalam penyusunan laporan keuangan akuntansi berbasis akrual.

\section{KESIMPULAN}

Hasil dari penelitian ini menunjukan bahwa pemerintah kota Kupang telah menerapkan SAP berbasis akrual. Hal tersebut dilihat dari jumlah pegawai yang berjumlah 232 orang, sarana dan prasarana serta aplikasi SIPKD yang memadai namun belum optimal. Selain itu, komunikasi antar pimpinan dengan pegawai berjalan dengan baik walaupun sosialisasi akan suatu kebijakan atau informasi baru masih terbilang kurang. Komitmen atau sikap dari BKD Kota Kupang dalam menjalankan setiap kebijakan cukup tinggi dan SOP yang digunakan juga telah sesuai dengan panduan yang diberikan oleh Pemerintah Pusat. Namun, penerapan atas SAP berbasis akrual masih belum terlaksana secara optimal. Hal ini dilihat dari masih adanya beberapa kendala yang terjadi, antara lain kualitas dan latar belakang pendidikan pegawai yang kurang memadai, penguasaan atas aplikasi SIPKD belum secara penuh diterapkan sehingga masih mengandalkan satu orang pegawai dalam membuat penyusunan laporan keuangan secara manual, keterlambatan laporan dari SKPD, serta proses mutasi pegawai yang belum dilaksanakan secara terstruktur.

\section{IMPLIKASI PENELITIAN}

Penelitian ini memberikan implikasi terhadap beberapa pihak. Secara khusus, penelitian ini memberi pengetahuan yang lebih mendalam akan implementasi SAP berbasis akrual terhadap pemerintah kota Kupang. Selain pemerintah kota Kupang, Pemda lain yang masuk dalam lingkup Provinsi Nusa Tenggara Timur juga dapat melihat dan mempelajari lebih lagi, sehingga dapat berguna bagi penyusunan dan pelaporan keuangan di daerah masing- 
masing. Selain itu, penelitian ini dapat memberikan gambaran lebih kepada Kementerian Keuangan sebagai pihak yang membuat kebijakan dalam pelaporan keuangan dari Pemerintah Daerah. Berbagai kendala yang masih terjadi dapat diminimalisir dengan kebijakan-kebijakan baru yang dibuat.

\section{REFERENSI}

Arikunto, S. (2006). Prosedur penelitian suatu pendekatan praktik. Jakarta: Rineka Cipta.

Azmi, A. H. \& Mohamed, N. 2014. Readiness of Malaysian public sector employees in moving towards accrual accounting for improve accountability: The case of Ministry of Education (MOE). Procedia-Social and Behavioral Sciences, 164: 106-111.

Dollah, K., Saerang, D. P., \& Manossoh, H. 2017. Analisis Implementasi Standar Akuntansi Pemerintahan Berbasis Akrual Pada Pemerintah Kabupaten Bolaang Mongondow Utara. JURNAL RISET AKUNTANSI DAN AUDITING “GOODWILL", 8(1): 256-265.

Herwiyanti, E., Sukirman \& Aziz, F. Z. 2017. Analisis Implementasi Akuntansi Berbasis Akrual pada Inspektorat Jenderal Kementrian Keuangan. Jurnal Akuntansi dan Keuangan, 19(1): 13-23

Hladika, M., Vašiček, V. \& Dragija, M. 2013. Challenges in Management the transition from cash to accrual accounting in the public sector. JEL: M 40, 41, 48:528- 538 .

Kimbal, D. A. \& Rahyuda, A. G. 2015. Pengaruh Self- Efficacy, Lingkungan Kerja Dan Dukungan Atasan Terhadap Transfer Pelatihan Pada Karyawan Bank Pembangunan Daerah (BPD) Bali Cabang Renon. EJurnal Manajemen Udayana, 4(11):3537-3564.

Lunenburg, F. C. 2011. Self-Efficacy in the Workplace: Implications for Motivations and Performance. International journal of management, business, and administration, 14(1):1-6. 
Maimunah, M. 2016. Implementation of Accrual Accounting: Review of Readiness and Arising Problems. Procedia-Social and Behavioral Sciences, 219:480-485.

Nazir, M. 2005. Metode Penelitian. Jakarta: Ghalia Indonesia

Pratama, A. 2012. Difficulties of accrual accounting implementation in Indonesia Government: a comparative study. Jurnal akuntansi Multiparadigma, 3(2):287-296.

Putra, I. W. G. Y. D. \& Ariyanto, D. 2015. Faktor-faktor yang mempengaruhi penerapan Standar Akuntansi Pemerintahan berbasis akrual. E Jurnal Akuntansi, 14-32.

Pristiani, P. \& Mahmud, A. 2016. Perbedaan pemahaman Standar Akuntansi Pemerintahan (SAP) berbasis Akrual bedasarkan demografi Pegawai. Accounting Analysis Journal, 5(1):1 - 8.

Sari, D. P. \& Putra, H. S. 2012. Menelisik Akuntansi Pemerintahan Berbasis Akrual. Jeam Vol XI No. 2/2012, 1-24.

Sugiyono. 2009. Metode Penelitian Kuantitatif, kualitatif, dan RED. Bandung: Alfabeta.

Tarigan, E. P. A. \& Nurtanzila, L. 2013. Standar Akuntansi Pemerintahan dalam Mewujudkan Akuntabilitas dan Transparansi Pengelolaan Keuangan Daerah. JKAP (Jurnal Kebijakan dan Administrasi Publik), 17(1):29-45.

Widyastuti, N. M. A., Edy Sujana, S. E., \& Adiputra, I. M. P. 2015. Analisis kesiapan Pemerintah Daerah dalam menerapkan Standar Akuntansi Berbasis Akrual di Kabupaten Gianyar. JIMAT (Jurnal Ilmiah Mahasiswa Akuntansi) Undiksha, 3 (1):1-12.

Wiryaningsih, N. N. D., Sulindawati, N. L. G., \& Prayudi, M. A. (2017), Analisis Penerapan Peraturan Pemerintah Nomor 71 Tahun 2010 Tentang Standar Akuntansi Pemerintah Berbasis Akrual Pada Rumah Sakit Umum Kabupaten Bangli. E-Journal Akuntansi Universitas Pendidikan Ganesha, $8(2)$. 
Jati, B. P. (2019). Pengaruh Penerapan Standar Akuntansi Pemerintahan Berbasis Akrual Terhadap Kualitas Laporan Keuangan Pemerintah Daerah. Wahana, 21(1).

Ayu, P. C., \& Kusumawati, N. P. A. (2020). Pengaruh Penerapan Standar Akuntansi Pemerintahan Berbasis Akrual, Kompetensi Sumber Daya Manusia dan Pengendalian Intern Terhadap Kualitas Laporan Keuangan Pemerintah Kabupaten Gianyar. Widya Akuntansi dan Keuangan, 2(1).

Wahyuni, N. E. (2016). Analisis Implementasi Standar Akuntansi Pemerintahan Berbasis Akrual dalam Perspektif Teori Institusional: Studi Kasus pada Pemerintah Kota Malang. Jurnal Ilmiah Mahasiswa FEB, 4(1).

Supraja, G. (2019). Pengaruh Implementasi Standar Akuntansi Pemerintahan Berbasis Akrual dan Efektivitas Fungsi Pengawasan Terhadap Kinerja Keuangan Pemerintah Daerah Kabupaten Deli Serdang. Jurnal Akuntansi Bisnis dan Publik, 10(1).

Safitri, D. (2017). Faktor Faktor Yang Mempengaruhi Penerapan Standar Akuntansi Pemerintahan Berbasis Akrual (Studi Pada SKPD Pemerintah Kabupaten Bengkalis). Jurnal Akuntansi, 5(2).

Safitri, A., Heriyanto, M., \& Ibrahim, M. (2017). Analisis Penerapan Standar Akuntansi Pemerintahan Berbasis Akrual. Jurnal Ilmu Administrasi Negara, 14(3).

Asmiputri, R., \& Jati, A. W. (2014). Analisis Penerapan Standar Akuntansi Pemerintah Berbasis Akrual Pada Peraturan Pemerintah No. 71 Tahun 2010 dalam Penyajian Laporan Keuangan Sekretariat UAPPA/B-W Kementrian Pertanian Provinsi Nusa Tenggara Barat. Jurnal Reviu Akuntansi dan Keuangan, 4(2).

Nin, F. A. L., Karamoy, H., \& Tangkuman, S. (2014). Analisis Penerapan Pp. No. 71 Tahun 2010 Dalam Penyajian Laporan Keuangan Dinas Pendapatan Pengelolaan Keuangan Dan Aset Daerah Kota Kotamobagu. Jurnal $E M B A, 2(4)$. 
Langelo, F., Saerang, D. P. E., \& Alexander, S. W. (2015). Analisis Penerapan Standar Akuntansi Pemerintahan Berbasis Akrual Dalam Penyajian Laporan Keuangan Pada Pemerintah Kota Bitung. Jurnal EMBA, 3(1).

Ranuba, E. D. S., Pangemanan, S., \& Pinatik, S. (2015). Analisis Kesiapan Penerapan Standar Akuntansi Pemerintah Berbasis Akrual Berdasarkan Pp No. 71 Tahun 2010 Pada Dpkpa Minahasa Selatan. Jurnal EMBA, 3(1). Sitorus, S., Kalangi, L., \& Walandouw, S. K. (2015). Analisis Kesiapan Penerapan Standar Akuntansi Pemerintah Berbasis Akrual Berdasarkan Pp. No. 71 Tahun 2010 Pada Dinas Pendapatan Pengelolaan Keuangan dan Barang Milik Daerah Kota Tomohon. Jurnal EMBA, 3(1).

Putra, I. W. G. Y. D., \& Ariyanto, D. (2015). Faktor-Faktor yang Mempengaruhi Penerapan Standar Akuntansi Pemerintahan Berbasis Akrual. E-Jurnal Akuntansi Universitas Udayana, 13(1).

Lamonisi, S. (2016). Analisis Penerapan Standar Akuntansi Berbasis Akrual Pada Pemerintah Kota Tomohon. Jurnal EMBA, 4(1).

Satrio, M. D., Yuhertiana, I., \& Hamzah, A. Implementasi Standar Akuntansi Pemerintah Berbasis Akrual di Kabupaten Jombang. Jurnal Akuntansi dan Keuangan, 18(1).

Herwiyanti, E., Sukirman, S., \& Aziz F. S. (2017). Analisis Implementasi

Akuntansi Berbasis Akrual pada Inspektorat Jenderal Kementerian Keuangan. Jurnal Akuntansi dan Keuangan, 19(1).

Sudaryati, E., \& Permana, T. D. (2020). Analisis Penerapan Standar Akuntansi Pemerintahan Berbasis Akrual Pada Dinas Kehutanan Provinsi Jawa Timur. Berkala Akuntansi dan Keuangan Indonesia, 5(1).

Motoh, J. F., Tinangon, J. J., \& Warongan, J. D. L. (2020). Analisis Penerapan Standar Akuntansi Pemerintahan untuk Belanja Pada Dinas Kesehatan Kota Manado. Indonesia Accounting Journal, 2(1).

Azman, T. (2015). Analisis Komitmen Organisasi, Kesiapan Sumberdaya Manusia, Infrastruktur Serta Sistem Informasi Dalam Menerapkan 
Standar Akuntansi Pemerintah Berbasis Akrual (Studi pada Pemerintah Kabupaten Kepulauan Meranti). Jurnal Sorot, 10(1).

Pasi, N., Kadir, A., \& Isnaini, S. (2017). Implementasi Sistem Informasi Manajemen Daerah Keuangan Berbasis Akrual pada Pemerintah Kabupaten Dairi. Jurnal Administrasi Publik, 7(1). 